\title{
HISTORY OF CLUB DEVELOPMENT IN UKRAINE
}

\section{Liudmyla Polishchuk}

\section{INTRODUCTION}

The history of clubs as socio-cultural institutions is closely related to the history of the country as a whole. Changes in the socio-political structure of the country have always influenced the socio-cultural sphere, the content and direction of cultural institutions depended on the ideology of the ruling elite, and their model was formed.

At the present stage, there are almost no works devoted to domestic clubs of the pre-revolutionary era (before 1917). Only a few sources from the field of extracurricular education and overcoming illiteracy among peasants and workers, which characterize the activities of clubs of the pre-Soviet period, have been preserved. Among them are the works of A. Obukhov, K. Sadyrin, $\mathrm{H}$. Cherkezov, who investigate the issues of out-of-school tutoring of children, peculiarities of organization of national universities and activities of district organizations of out-of-school education, etc.

In the first studies of the Soviet period, cultural and educational activities of clubs are considered mainly as a means of ideological influence on people (V. Zelenko, N. Krupska, Ye. Medynskyi, M. Petrovskyi, S. Siropolko, L. Frid, M. Tzariev-Luniev, S. Shatskyi and others). The works of Soviet scientists were aimed at exploring the possibilities of realizing the political and educational potential of the clubs, as evidenced by studies by B. Berezin, Ye. Zazerskyi, L.Kohan, Ye. Smirnova and others.

The second stage of club studies (the ' 60 s of the 20th century) began with the works of O. Sasikhov and Y. Streltsov (Fundamentals of Club Studies), which revealed the democratic nature of the club and its socio-communicative function as an active dominant. The author of the first textbooks on club studies D. Henkin, S. Ikonnikova, V. Kovsharov, M. Skrypniev and A. Solomonik, substantiated the scientific foundations of the club activities. The ' 60 s-' 80 s of the 20th century are considered the most productive period in the formation and development of club studies. A significant contribution to its development belongs to M. Ariarskyi, H. Yevtieva, E. Zazerskyi, L. Kohan, Yu. Krasilnikov, M. Maksiutin and Ye. Smirnova, etc. During this period, the history of cultural and educational work in the USSR was actively researched. This issue is devoted to the thorough works of M. Andreieva, A. Vynohradov, S. Pinalov and H. Cherniavskyi, in which the clubs were considered in the context of the history of cultural and educational work. 
During the perestroika, interest in the theory and practice of the club business decreased significantly, this is explained by the change in cultural values. The clubs were perceived as an anachronism, as an example of ideologized institutions of the administrative-command system, which fulfil an ideological-educational function in the sphere of leisure, which caused the alienation of a large part of the population, especially young people. Authors of researches of 1980s of 20th century considered the possibilities of reprofiling the clubs into public centres of self-education, unregulated communication, spiritual development and active rest of the population (N. Zaporozhets, A. Leonova, O. Myroniuk, O. Sknar, N. Tarasiuk and E. Chmykhalo, etc.).

A qualitatively new period in the study of club work begins with the proclamation of state independence of Ukraine when clubs are regarded as sociocultural institutions whose task is to meet the needs of the population in recreation, health, training, development of creativity and leisure organization. Contemporary research authors are expanding club science by addressing the club's methodological and theoretical issues, N. Babenko, O. Hrytsenko, G. Yeskina, Y. Kliuchko, A. Myronenko, N. Ostanina, I. Petrov, N. Samoilenko, O. Terekhov and $\mathrm{N}$. Tsymbaliuk, etc. addressed various aspects of club activity.

Despite the considerable number of scientific publications on the problems of club activities, Ukrainian club studies lack comprehensive studies of the history of the development of domestic clubs, especially the period before the beginning of the twentieth century (that is, before the revolutionary events of 1917). Such a scientific gap shapes the attitude of the population to the clubs exclusively as to the achievements of the Soviet era, which negatively affects the activity of modern Ukrainian clubs and the forecasting of their further development.

\section{The Origins of Club Activities}

The club as a social institute was born in a primitive society in the form of 'men's houses', which were a kind of community centres, a meeting place for a community council, a reception, a dining room, a place for relaxation and communication. They were of great social importance in the ancient world ${ }^{1}$.

\footnotetext{
${ }^{1}$ Volodina O. V. (2014) Realizatsiya pedagogicheskogo potentsiala uchrezhdeniya kul'tury klubnogo tipa [Realization of the pedagogical potential of a club-type cultural institution] $(\mathrm{PhD}$ Thesis), - Stavropol', Severo-kavkazkiy gosudarstvennyy tekhnicheskiy universitet; Tuev V. V. (1997) Istoriya kluba : ot neinstituirovannykh form klubnogo obshcheniya do pervykh organizatsiy klubnogo tipa [Club history: from non-institutional forms of club communication to the first club type organizations]. Kemerovo: KGIIK (in Russian); Tuev V. V. (1998) Fenomen kluba : Istoriko-pedagogicheskiy analiz [Club Phenomenon: Historical and Pedagogical Analysis] (PhD Thesis), Moskva: Moskovskiy gosudarsvennyy universitet kul'tury.
} 
In practical life, every native-born in Athens belonged to such public associations as phil or fraternity, and representatives of the nobility: even to political clubs, heteri, headed by aristocratic and democratic leaders. During the heyday of policies, these entities emerged for private purposes, but they did not contradict the interests of the state as a whole. By the beginning of the 6th century B.C., merchant companies, religious associations, even piracy societies were created. Religious associations (the most common among them are the Oregonians and the Fiasas) were organized not only for protection against external threats and harassment, but also for the purpose of joint leisure and rest. Reasons for identifying such associations with clubs give them common features: democracy and self-government, the existence of rules for members of associations or associations, community organizations ${ }^{2}$.

The prototypes of modern clubs in the ancient world were the ghetteries, which functioned as political associations of like-minded people, philosophical unions, or secret, opposition-to-power organizations; Circles (circuli), which brought together the opposition intelligentsia who were going to discuss political, philosophical or literary issues; terms in which to meet with likeminded people, joint rest and recreation. In some thermae, there were libraries, reading rooms, literary, music and picture halls, galleries for walks, restrooms, gardens and fountains, which attracted a large number of people ${ }^{3}$.

In the era of the 'corporate' Middle Ages, everyone, regardless of their social status, was a member of a particular group or association. Vassal unions, knightly associations and orders, monastic brotherhoods and catholic clergy, city communes, merchant guilds and professional workshops, protective associations, rural communities, blood relatives unions, patriarchal and individual family groups combined individuals into the close, individual their participants' protection and assistance. Each group had its own rules as a charter (statute), a code of conduct, rules that are binding on all members of the team. Social relationships within such corporations were built not vertically, but horizontally, requiring each group member to have a certain discipline, a related lifestyle, and even opinions, to adhere to certain stereotypes of behaviour. The principle of equality of members of the corporation was its constituent feature even when it was not observed in practical life ${ }^{4}$.

2 Ustinova Yu. B. (1988) Chastnye kul'tovye soobshchestva u grekov [Private cult communities of the Greeks]. Byt $\mathrm{i}$ istoriya $\mathrm{v}$ antichnosti [Life and history in antiquity]. Moscow: Nauka, pp. 192-218.

${ }^{3}$ Verzhbitskiy K. V. (1999) Traditsionnye formy obshcheniya u rimlyan i oppozitsiya Yuliyam-Klavdiyam [Traditional forms of communication among the Romans and opposition to Julius-Claudius], Vestnik Sankt-Peterburgskogo universiteta, vol. 2, pp. 104-107.

${ }^{4}$ Gurevich A. Ya. (1972) Kategorii srednevekovoy kul'tury [Categories of medieval culture]. Moscow: Iskusstvo. (in Russian) 
However, the first prototypes of clubs, in the modern sense, emerged as club rooms in English taverns at the end of the 16th century. The tavern, thanks to its accessibility and openness, has been a favourite pastime for many of its visitors. It is known that the founder of the first club in the Mermaid Tavern was Walter Raleigh and the members of the club were Beaumont, Fletcher and Shakespeare ${ }^{5}$. It was in England that the perception of the club as an institute of culture was formed, manifested in the selectivity of communication, the localization of leisure space and the shared interests. From here, there are three main types of clubs tested in English socio-cultural practice: clubs associations at taverns and coffee shops; tubers eating for political, professional, literary and other interests; clubhouses specially designed and built for multifunctional leisure activities. The main activities of the clubmen in English clubs were communication and leisure, so communication and leisure functions prevailed. As a complete system of leisure activities, English clubs were able to satisfy the demands of different socio-demographic groups, although access to them by female members was severely restricted ${ }^{6}$.

In the 19th century, intensive development of English club practice acquired. In England, there were two tendencies in the development of clubs: the first tendency related to the content of leisure activities, resulting in the formation of sports, dance, religious, music clubs; the second tendency aimed at the socio-cultural organization of clubs with a clear socio-demographic orientation, which resulted in student, women's, teenagers and other clubs. The involvement of people in the club movement took place through vertical social relations, which was especially evident in aristocratic, elite clubs that united statesmen, diplomats, financiers, businessmen, famous writers and journalists. The tendency to involve the English in club life was ensured by a well-established system of school and university education: the 'club tradition' was instilled in young people on the school bench. In every English school, a compulsory 'club set' was distributed: athletic sports clubs, leather ball clubs, golf clubs and discussion boards, etc ${ }^{7}$.

Thus, English clubs represent the first-ever compromise between two natural needs of people: self-sufficient cohesion and leisure communication. During the first centuries of the existence of English clubs, the essential

${ }^{5}$ Izdateli Brokgauz, Efron (1900) Klub [Club]. Entsiklopedicheskiy slovar' [Encyclopedic Dictionary]. Cankt-Peterburg, pp. 1119.

${ }^{6}$ Vyguzova E. V. (2005) Elitarnye kluby v kul'turnom prostranstve Rossii kontsa XVIII nachala XX vv. [Elite clubs in the cultural space of Russia in the late 18th - early 20th centuries] (PhD Thesis), Ekaterinburg: Ural'skiy gosudarstvennyy universitet im. A. M. Gor'kogo

${ }^{7}$ Komissarenko S. (1997) Angliya : klubnye traditsii [England: club traditions]. Klub, no. 11, p. 18. 
principles of their activities were formed, which subsequently became a model for club associations in other countries: the voluntary nature of the association; the right of the club members to choose the program and content of the activity independently; separation from the external environment, which was intended to cause its members 'euphoria of freedom', independence from society; the existence of specific 'rules of the game' and the obligation of their observance by the club members; an extensive system of club self-government; availability of club symbols and other 'club' property; the elitist character of the club and the corporate pride of its members.

British scientists have identified five major principles of English clubs:

1. The combination of openness and exclusivity. On the one hand, the club creates the illusion of openness ('for all-comers'), on the other hand, it uses various means of 'personnel' sustainability, 'election' by introducing membership and a specific procedure for its granting.

2. Combining mobility and micro-sociality: clubs are small social groups that, in turn, are divided into even smaller circles, united by friendships and a keen sense of common ownership of something (from shared relics to shared ideas and tastes);

3. The combination of 'profile' and 'sociality'. Even clubs set up for 'non-political' interests, necessarily carry out public events (discos, carnivals, parties and donations), not related to the motives of formation. Sports clubs, most indicative of social openness, are due to the specificity of sports, its focus on different social strata.

4. Depending on the meeting place (premises, playground), etc. This factor encourages the active cooperation of clubs with various institutions, commercial companies and local authorities, which are most often the benefactors of the clubs, providing premises for their activities.

5. The acquisition of a new socio-cultural identity (i.e. a temporary change in its social role) as a major psychological motive for involving citizens in club activities. Entrepreneurs, workers, housewives for some time become informal leaders, commanders, coaches and social service workers, etc ${ }^{8}$.

In the territory of the former USSR, the first club was established in Petersburg in 1770. V. Zhukovskyi, M. Karamzin, I. Krylov and O. Pushkin took an active part in the life of the so-called 'English club'. Subsequently,

${ }^{8}$ Darvin B. British clubs (British in pictures). - London, 1943. - 48 p.; Fitzgerald P. The History of Pickwick. - London, 1891. - 375 p.; Griffiths M.A. Clubs and clubmen. - London, Hutchinson and Co. - London, 1907. - 343p.; Timbs J. Club life of London during the 17th, 18th and 19 th centuries. In two volumes. - London, 1866. - V.1. - 364 p.; Wertheimer J. The Law relating to clubs by M. Turner and A. S. Wilson. - London : Swell and Maxvell, 1903. - $236 \mathrm{p}$. 
such clubs appeared in major cities of the Russian Empire. Clubs of prerevolutionary Russia were distinguished by the class character, which is reflected in their name: nobility, boyars, merchants; the elitism and the regulated nature of club membership; stringent conditions for joining the club; conservativeness and tradition; aristocratic service; an atmosphere of comfort, comfort and sophistication; availability of relevant documents regulating the activities of clubs ${ }^{9}$.

In Ukraine, in the 19th century, a common version of the clubs was also 'gatherings' by the class as nobility, merchants and officers. They were created practically in all provincial cities, had restaurants, concert halls, even parks (for example, the Merchant Assembly in Kyiv as the Merchant Garden).

The model of the English club in Ukraine was the Noble club, which was established in 1838 in Kyiv, on Khreshchatyk Str. Its main activity was the organization of leisure nobles: the club held balls, masquerades, card games and billiards. Despite the fact that the club was closed, during 1883-1884, it was systematically organized folk readings. Reports of the People's Reading Commission in Kyiv indicate that it was the Noble Club that received the highest number of listeners (mostly representatives of the urban population): in $1883-7,073$, and in $1884-12,175$ people $^{10}$. Such an example confirms the participation of members of the Noble Club in the public life of the city.

In 1849 the Odessa Noble Assembly was opened in Odessa. Unlike the English club, which acted as an institution 'from the outset inaccessible to the so-called middle class', the Odessa noble assembly was a relatively democratic and open leisure structure, which systematically arranged family evenings, but 'there were so many people wishing to attend these balls that even the large premises of the Richelieu Hotel could not accommodate them, ${ }^{11}$.

The noble gatherings of the 19th-20th centuries, which were created and operated in almost every provincial centre, reflected the original phenomenon of the club with all the characteristic features of communicative and leisure mentality: the class principle of association of people in socio-cultural societies; closed to outsiders; solidarity and expressed interest in the interests of club members. Over time, the social base of clubs expanded, which was

\footnotetext{
${ }^{9}$ Berezin B. I. (1989) Sovetskiy klub : sostoyanie i perspektivy razvitiya [Soviet club: state and development prospects]. Moscow: VIPKRK. (in Russian)

${ }^{10}$ Komissiya narodnykh chteniy v Kieve (1888) Otchet komissii narodnykh chteniy v Kieve za $1882-1887 \mathrm{gg}$. [Report of the commission of public readings in Kiev for 1882-1887]. Kiev: Tipografiya shtaba Kievskogo voennogo okruga. (in Ukrainian)

11 Cherkezov G. (1912) Vneshkol'noe popechenie o detyakh [Extracurricular care for children]. Prakticheskaya shkol'naya entsiklopediya [Practical School Encyclopedia]. - Moscow: Tipografiya T. P. Ryabushinskogo, pp. 709-715.
} 
driven by their popularity among various segments of society. The most characteristic of the class principle was among people of the same social status, origin, educational level and property status, which ensured corporate elitism. The legal status of the clubs consists of a fixed membership, an established and self-governing style of self-governance, strict adherence to the club members' code of rules, stereotypes and stamps of club behaviour.

Although clubs and so-called balls were organized in large cities, traditional gatherings of young people 'streets', 'music', 'evening', 'party' and 'sunrise' were popular in Ukrainian villages and towns, during which youth combined work with leisure hobbies (songs, dances, games, jokes and fables, etc.). For such gatherings, rooms (rooms, one of the club's values as 'club room') were rented, rooms were invited, musicians were invited and joint parties were organized. The main purpose of such gatherings was acquaintance, communication, rest and entertainment ${ }^{12}$. The main community centres of the traditional village were the church and the square near the church as centres of spiritual and religious unity of the laity. The Ukrainian churches used the experience of work of organizations of a semi-church nature as fraternities (honey fraternities), which were created in the $15^{\text {th }}$ century to maintain order in churches, close ties with the fraternities (congregations of members of rural communities, artisan corporations, etc.), to organize collective prayers in honour of their patron saint and common feast. The main purposes of the church square were to direct public life and provide festive leisure. They came here to solve social problems, to communicate, to listen to stories and songs of wandering lyricists, kobza (lute) players, bandura players, to take part in folk festivities and entertainments ${ }^{13}$.

The integral parts of a traditional Ukrainian village or village were taverns or ham, which can also be called a kind of country club. After all, people gathered here to exchange information, hear news and listen to music. In the cold season, dinners, dances took place in the tavern or ham, and families came here on holidays ${ }^{14}$.

12 Bosyk Z. O. (2010) Vechornyci ta dosvitky [Evenings and sunrises]. Pam'jatkazapytaljnyk na dopomoghu zbyracham ukrajinsjkoji usnoji narodnopoetychnoji tvorchosti [Questionnaire for help to collectors of Ukrainian oral poetry]. Kiev: NAKKKiM, pp. 46-51.; Ponomarjov A. (1996) Tradycijni normy povedinky i dozvillja [Traditional standards of behavior and leisure]. Etnichnistj ta etnichna istorija Ukrajiny [Ethnicity and Ethnic History of Ukraine] (Elektronnyj resurs). Retrieved from: http://libr.org.ua/book/78/2397. html (accessed 10.12.10).

${ }^{13}$ Ponomarjov A. (1996) Tradycijni normy povedinky i dozvillja [Traditional standards of behavior and leisure]. Etnichnistj ta etnichna istorija Ukrajiny [Ethnicity and Ethnic History of Ukraine] (Elektronnyj resurs). Retrieved from: http://libr.org.ua/book/78/2397.html (accessed 10.12.10).

${ }^{14}$ Ponomarjov A. (1996) Tradycijni normy povedinky i dozvillja [Traditional standards of behavior and leisure]. Etnichnistj ta etnichna istorija Ukrajiny [Ethnicity and Ethnic History of Ukraine] (Elektronnyj resurs). Retrieved from: http://libr.org.ua/book/78/ 2397. html (accessed 10.12.10). 
In the second half of the 19th century in the countries of Central and Eastern Europe, clubs, coteries, cultural and educational associations were established, among which the most influential were Lviv 'Enlightenment', Kyiv 'Old Community' and others. Thus, the Enlightenment Society, founded in 1868 in Lviv, numbered 73 branches and 2,944 reading rooms in 1914; in 1939 , their number increased to 83 branches, covering 360,000 members ${ }^{15}$ and had 3,208 readings, 2,065 dramatic circles, 1,105 choirs, 104 orchestras, 439 self-educational circles, 533 'Young Enlightenment' circles, 845 fans of Ukrainian books and others ${ }^{16}$. Through printed media, literary, theatrical, vocal, choreographic and musical circles, the society promoted Ukrainian culture among the population.

Cultural and educational work among the population was also carried out by the Kharkiv and Kyiv Writing Societies, the Odesa Slavic Society, the Chernivtsi 'Russian Conversation', etc ${ }^{17}$. . In 1908, the 'Ukrainian Club' was established in Kyiv, the participants of which organized concerts, theatrical performances, reading books, engaging students in social and cultural activities. But both it and most of the 'Enlightenments' were closed during 1910-1912. Such a 'traditional' history with the clubs of the Ukrainian intelligentsia will be repeated at least twice: in the early 1960s, when the Kyiv Creative Club became a catalyst for the Sixties but was soon forbidden, and in 1987-1988, when the semi-illegal Ukrainian Cultural Club became a harbinger of Ukrainian opposition organizations like the Ukrainian Language Society (ULC), Rukh and the Ukrainian Radical Party (URP) ${ }^{18}$.

At the end of the 19th and early 20th centuries with the disappearance of the aristocracy as a separate social group in the structure of society, aristocratic clubs ceased to exist. Instead, 'people's houses' appeared, the most famous of which was the 1903 People's House of the Kharkov Literature Society. There was a lecture room, a library, a reading room and a music hall in his room.

Like the people's houses in the early 20th century 'People's Universities' (Kyiv, Kharkiv, Simferopol and Chernihiv), whose main task was not to educate, but to educate the people, became widespread: 'the university means serving the educational needs of the pariahs of Russian enlightenment, i.e. the

${ }^{15}$ Ghrycenko O. A. (1998) Klub [Club]. Narysy ukrajinsjkoji populjarnoji kuljtury [Essays on Ukrainian Popular Culture]. Kiev: UCKD, pp. 245-259.

16 Fostun S. M. (1999) 130-richchja Tovarystva "Prosvita" [Prosvita Society's 130th Anniversary], Vyzvoljnyj shljakh : suspiljno-politychnyj i literaturnyj misjachnyk, vol. 1, pp. 13-24.

17 Zakovych M. M. (ed.) (2004) Kuljturologhija : ukrajinsjka ta zarubizhna kuljtura [Culturology: Ukrainian and foreign culture]. Kiev: Znannja. (in Ukrainian)

${ }^{18}$ Ghrycenko O. A. (1998) Klub [Club]. Narysy ukrajinsjkoji populjarnoji kuljtury [Essays on Ukrainian Popular Culture]. Kiev: UCKD, pp. 245-259. 
disadvantaged in cultural relations ${ }^{19}$. Visitors to popular universities received 'neither diplomas, nor careers, nor bureaucrats, no direct benefits from this knowledge; it strives for it 'for the soul' sees in it the source of satisfaction of his/her moral personality' ${ }^{20}$. People's universities organized 'People's Conservatories', 'People's Theatres', literary and musical evenings, cinema screenings, and organized excursions.

\section{Activities Clubs of the 20th century}

The history of Soviet clubs in Ukraine begins in the post-revolutionary years of the twentieth century, when the merchant, noble, educational clubs were completely destroyed, and replaced by the Soviet model of the club: the red corner, the reading room, the village club, and the Palace of Culture.

The first Soviet clubs were political in nature, and their creation in Ukraine (as in the USSR in general) was the result of the revolutionary events of 1917, the ideologists and organizers of Soviet clubs used the principles of creating class aristocratic clubs, adapted to agitate and propagate ideas of the Bolshevik authorities.

Not only clubs but also new kinds of club-type institutions: cultural and educational groups and agitation and educational centres (in Ukraine in the late 1920s, there were more than 80 such agitation points), their main forms of work were performances, lectures, reports, conversations, agitation plays, newspapers and leaflets of propaganda content.

In rural areas, the cultural needs of the population were met by red corners, rural buildings and reading rooms. The Red Corner became a form of mass political education that embraced the peasantry and invisibly but firmly combined political education with peasant life. Political education in such corners was carried out by red readers, selected among demobilized Red Army men, teachers, party and Komsomol members, village council members, peasants, cultural workers, and rural builders ${ }^{21}$.

Clubs (Komsomol, school, party and workers) played a leading role in the system of leisure institutions at this time: 'the Soviet regime put on a 'red enlighten' rural clubs and won at a crucial time for itself in 1929-1933, at least some critical share of the younger generation Ukrainians, whose hands

19 Sadyrin K. (1912) Narodnye universitety [People's universities]. Prakticheskaya shkol'naya entsiklopediya [Practical School Encyclopedia]. Moscow: Tipografiya T. P. Ryabushinskogo, pp. 597-614.

20 Sadyrin K. (1912) Narodnye universitety [People's universities]. Prakticheskaya shkol'naya entsiklopediya [Practical School Encyclopedia]. Moscow: Tipografiya T. P. Ryabushinskogo, pp. 597-614.

${ }^{21}$ Baghmut I. A. (1927) Chervoni kutky na seli (kutkovi khaty chytaljni) [Red corners in the countryside (corner reading rooms)]. Kiev: Derzhavne vydavnyctvo Ukrajiny. (in Ukrainian) 
were made and collectivization and dispossession and seizure of grain in $1933^{22}$. Party organization was responsible for setting up the club business, communists and experienced political workers were sent to work in the clubs. In order to coordinate club work in the countryside, the post of district inspector for collective farms, reading rooms and red corners was introduced. The clubs combined a library, a cinema, a dance hall, amateur circles and it was in their multi-functionality that their advantage lay ${ }^{23}$.

On the one hand, club activities were enriched with forms and methods of work that met the requirements of the new political order. Much attention was paid to the development of agitation and propaganda forms of work: agitation points, agitation parades, agitation storm, agitation trade, political courses, rallies, concerts and political reports. The ideas of political education were spread by publishing leaflets, posters and live newspapers. The practice of artistic illustration, which promoted active and conscious assimilation of knowledge, developed thematic evenings, educational cycles (geographical, literary, art, artistic and economic), staged social courts (industrial, political, historical and pedagogical) justified itself. Work in mugs and studios has been linked to local examples and facts, providing accessibility and simplicity to the most complex material ${ }^{24}$.

In the course of the political and educational work of the club during this period, the following directions prevailed: propaganda of Leninism in circles of political literacy, Lenin circles and corners through talks, reports, lectures, live newspapers, staging, etc.; promotion of trade unions whose purpose is to promote and explain the main tasks of trade unions, the rights and responsibilities of their members, the achievements of trade unions (protection of economic workers' interests, wage growth, labour protection, etc.); industrial education, which with the help of reports on production topics, interviews, lectures, staging, industrial exhibitions and production excursions.

Thus, the clubs of the first years of Soviet power played the role of centres of educational, agitation, political and educational work among the population. The analysis of their organization and activity shows that in their work the forms and methods of pre-revolutionary aristocratic unions were

\footnotetext{
${ }^{22}$ Ghrycenko O. A. (1998) Klub [Club]. Narysy ukrajinsjkoji populjarnoji kuljtury [Essays on Ukrainian Popular Culture]. Kiev: UCKD, pp. 245-259.

${ }^{23}$ Ghrycenko O. A. (1998) Klub [Club]. Narysy ukrajinsjkoji populjarnoji kuljtury [Essays on Ukrainian Popular Culture]. Kiev: UCKD, pp. 245-259.

${ }^{24}$ Petrova I. V. (2008) Kuljturologhichni chynnyky rozvytku dozvillja v Ukrajini pislja socialistychnoji revoljuciji [Cultural factors of leisure development in Ukraine after the socialist revolution], Visnyk Derzhavnoji akademiji kerivnykh kadriv kuljtury i mystectv, no.4, pp. 21-26.; Petrova I. V. (2005) Osoblyvosti funkcionuvannja sfery dozvillja u radjansjkij Ukrajini (1917-1939) [Features of Functioning of Leisure Sphere in Soviet Ukraine (1917-1939)]. Visnyk KNUKiM, vol. 13, pp. 117-124.
} 
sometimes used, but they were modified and adapted to promote a new, communist way of life. Soviet clubs not only promoted the ideas of the Soviet government but also monitored the actions and sentiments of the people, gradually but systematically, cultivating the revolutionary spirit and political patriotism.

During the same period, the centralization of all political and educational work was carried out, the main governing body of which was the Main Political and Educational Committee of the Republic, which strengthened the link between cultural and educational work, the policy of the state and organizations ${ }^{25}$.

In the early ' 30 s of the 20 th century, construction and opening of large club facilities, including trade union places of culture, was on-going. The motto of the All-Union Club Council 'Face to Production!' prompted the creation of cultural enterprises and cultural brigades. The main forms of work were red boards, showcases of social competitions, photo galleries of drummers, evenings on production topics, as well as 'blackboards', which, in contrast to 'red', criticized the lagging workers and the lazybones ${ }^{26}$. In the late ' 30 s, 20th century, reorganization of home reading rooms was carried out into collective farms for which special premises were built ${ }^{27}$.

Prior to the outbreak of World War II, ideological and patriotic work aimed at strengthening the foreign policy of the USSR, the Leninist doctrine of just and unjust wars, and fostering a love for the heroic past became particularly important. The club establishments organized defense corners, in which, in addition to materials on the fighting traditions of the people, the heroism of the Red Army, disseminated manuals that helped to acquire elementary military knowledge; meetings with Red Army heroes were organized; defensive circles worked; military games were held; outreach and outreach activities unfolded. The motives of love for the Motherland, its protection, pervaded all genres of amateur art, which contributed to the readiness of the Soviet people to fight against the German occupiers.

During World War II, club funding decreased, their network halved, their club work re-orientated to patriotic and public education, to different forms

${ }^{25}$ Zharkov A. D., Chizhikov V. M. (ed) (1998) Kul'turno-dosugovaya deyatel'nost' [Cultural and leisure activities]. Moscow: MGUK. (in Russian); Pinalov S. A., Chernyavskiy G. I., Vinogradov A. P. (1983) Istoriya kul'turno-prosvetitel'noy raboty v SSSR [The history of cultural and educational work in the USSR ].Kiev: Vishcha shkola. (in Ukrainian)

${ }^{26}$ Pinalov S. A., Chernyavskiy G. I., Vinogradov A. P. (1983) Istoriya kul'turno-prosvetitel'noy raboty $\mathrm{v}$ SSSR [The history of cultural and educational work in the USSR]. Kiev: Vishcha shkola. (in Ukrainian)

${ }^{27}$ Zharkov A. D., Chizhikov V. M. (ed) (1998) Kul'turno-dosugovaya deyatel'nost' [Cultural and leisure activities]. Moscow: MGUK. (in Russian) 
and methods (reading newspapers, essays, film demonstrations, photo meetings, 'lightning leaflets') of the events of the war, the propaganda of heroic deeds of Soviet people. Mobile clubs, agitation boats, agitation squadrons (on the fronts), agitation trains, agitation machines, agitation carts, agitation points, army houses and divisional clubs were created ${ }^{28}$.

In the summer of 1945, the Transcarpathian region was annexed to the Ukrainian SSR, where radical socio-economic and cultural transformations began immediately. On July 22, 1946, the Central Committee of the Communist Party (b) of Ukraine (CCCP(b)U) and the Council of Ministers of the USSR adopted a resolution "On Measures for the Development of the National Economy of the Transcarpathian Region for 1946", which provides for the establishment of more than 500 clubs in the Transcarpathian region ${ }^{29}$ the important ideological role of the clubs and the confidence of the authorities in the educational activity of the clubs in promoting communist ideas were confirmed.

On March 18, 1946, the Supreme Soviet of the USSR adopted a Five-year Plan, which was intended not only to restore the clubs destroyed during the war but also to significantly increase their number. Cultural institutions were built at the expense of the state budget and trade unions, collective farms, and industrial enterprises. At the beginning of 1951, the number of club facilities in the USSR significantly exceeded their pre-war number $(1941-118 \mathrm{~K}$, $1951-125.4 \mathrm{~K}$, of which $-28.5 \mathrm{~K}$ in Ukraine). One of the most important documents that significantly influenced the organization of activities of clubtype institutions was the resolution of the Central Committee of the Central Committee of the All-Union Communist Party (b) of Ukraine CCAUCP (b) "On the Organizational and Propaganda Work of Party Organizations in Connection with the Adoption of the Law on the Five-year Plan to Restore the Development of the National Economy of the USSR in 1946-1950 years". Clubs, reading rooms, houses and palaces of culture became the centres of mass lecture propaganda. In large industrial cities, specialized club-type establishments were opened like technology houses and houses of scientific and technical propaganda, the main task of which was industrial propaganda aimed at increasing the pace of implementation of the Five-year Plan. For this purpose, lectures were held in clubs, thematic evenings of scientific and technical direction were held, evenings on the exchange of production

${ }^{28}$ Zharkov A. D., Chizhikov V. M. (ed) (1998) Kul'turno-dosugovaya deyatel'nost' [Cultural and leisure activities]. Moscow: MGUK. (in Russian)

${ }^{29}$ Andreeva M. S., Vinogradov A. P., Pinalov S. A., Chernyavskiy G. I. (1970) Istoriya kul'turno-prosvetitel'noy raboty v SSSR. Sovetskiy period (1917-1969) [The history of cultural and educational work in the USSR. Soviet period (1917-1969)]. Khar'kov: KhGIK. (in Ukrainian) 
experience, evenings of professions, exhibitions were organized, and circles were organized.

Important areas of club activities were scientific, educational and antireligious work and aesthetic education. Amateur art teams were active at almost every club, which participated annually in the organized district, city, regional, republican and all-union surveys and competitions. In 1951, the Council of Ministers of the USSR adopted a Decree "On Selection of Folk Talents", according to which the republican committees for the arts and cultural and educational institutions were obliged to identify gifted youth, with the purpose of sending it to study in artistic and creative institutions and to work in professional artistic groups ${ }^{30}$.

In order to increase the effectiveness of clubs, inter-collective councils for culture were created, the first of which was in Ukraine in the early ' 60 s in the Novograd-Volyn district of Zhytomyr Oblast. Since the mid-1950s, many clubs have operated clubs of interest (amateur associations): youth political clubs, atheist clubs, associations for industrial interests, clubs of art lovers, native nature and others. The number of amateur participants at clubs, enterprises, collective and state farms increased; photo studios and film studios started functioning. The development of amateur creativity was stimulated by state and public organizations through the allocation of special funds, conducting creative reviews, competitions, festivals and exhibitions, etc ${ }^{31}$.

Thus, mid- $20^{\text {th }}$ century clubs continue to be centres of communist and patriotic upbringing, production, technical, and educational work. Sociocultural activities were carried out only partially, the vast majority of measures were directed not to involve the society in cultural activities, but to promote the socialist way of life, Marxism-Leninism teachings and ideas of the Communist Party. All work was carried out in a planned manner, tightly controlled by state authorities. A positive aspect should be considered that, with great attention to cultural and educational work, the party congresses in their directives and prospective plans for the development of the economy provided for the material strengthening of cultural and educational institutions, including clubs.

${ }^{30}$ Pinalov S. A., Chernyavskiy G. I., Vinogradov A. P. (1983) Istoriya kul'turno-prosvetitel'noy raboty v SSSR [The history of cultural and educational work in the USSR ].Kiev: Vishcha shkola. (in Ukrainian)

${ }^{31}$ Klyusko E. M. (1999) Kul'turno-dosugovaya deyatel'nost' naseleniya Rossii (may 19451985 gg.) : Teoretiko-metodologicheskiy i istoricheskiy aspekty [Cultural and leisure activities of the population of Russia (May 1945-1985): Theoretical, methodological and historical aspects]. Moscow: MGUKI. (in Russian) 
National universities of culture organized in the 1960s, whose main task was to raise communist consciousness of the masses, their ideological and aesthetic education, to promote new achievements of science, technology, and not to entertainment and culture. Operating within clearly defined ideological boundaries, Soviet clubs developed new approaches to promoting party ideas, the chosen strategy, and tactics of governing the country. Such work intensified during the periods of preparation and holding of congresses of the party, plenums of its central committee, a celebration of officially approved anniversary dates, evenings of labour glory, evenings in honour of Heroes of Socialist Labour, portraits of the winners of the socialist competition. Agitation and cultural teams were an important means of promoting the achievements of innovators and industry leaders ${ }^{32}$.

Since the mid-60s, systematic sociological research began, aimed at identifying the interests of workers in the field of culture, improving club services and providing the population with cultural institutions. Supportingexperimental clubs were created in each region (there were more than 50 of them in 1969), during 1966-1969 scientific and practical conferences were devoted to the improvement of club work ${ }^{33}$.

In the late " $60 \mathrm{~s}$ in accordance with the Regulations "On State Club Facilities" operated the following types of clubs: the district house of culture, townhouse of culture, village house of culture, village club and car club.

The role of club organizers was taken over by trade union and Komsomol organizations, public authorities (councils, commissions and committees). At the enterprises, institutions, educational institutions, lectures, talks, excursions, collective visits to theatres and museums, concerts and evenings after the graduation; there were sports sections, amateur associations, health groups and amateur groups.

The end of the '70s was characterized by increased attention of the party and Soviet bodies to cultural and educational work. At this time, the Resolutions of the Central Committee of the CPSU and the Council of Ministers of the USSR "On Measures to Further Improve the Cultural Service of Rural Population” (1977), "On the Basis for Further Development of Amateur Artistic Creativity" (1978) and "On Further Improvement of

${ }^{32}$ Klyusko E. M. (1999) Kul'turno-dosugovaya deyatel'nost' naseleniya Rossii (may 19451985 gg.) : Teoretiko-metodologicheskiy i istoricheskiy aspekty [Cultural and leisure activities of the population of Russia (May 1945-1985): Theoretical, methodological and historical aspects]. Moscow: MGUKI. (in Russian)

${ }^{33}$ Andreeva M. S., Vinogradov A. P., Pinalov S. A., Chernyavskiy G. I. (1970) Istoriya kul'turno-prosvetitel'noy raboty v SSSR. Sovetskiy period (1917-1969) [The history of cultural and educational work in the USSR. Soviet period (1917-1969)]. Khar'kov: KhGIK. (in Ukrainian) 
Ideological, Political and Educational Works" (1979). Club management began to centralize: by the end of 1980 , there were 6,000 rural centralized club systems operating in Ukraine designed to improve the conditions for socio-cultural activity of rural residents in small remote villages. The work of all clubs was carried out according to a single plan with the involvement of other cultural institutions and public organizations ${ }^{34}$.

Thus, decisive in the activities of clubs 1960s-1970s of the 20th century was mass political work, production, technical and educational propaganda. Among the most common forms of club work were advocacy lectures, thematic nights (evening-meetings, portraits and evenings of combat and labour glory, evenings-rallies and evenings-reports), oral magazines and amateur art reviews.

In the 1970s and 1980s, the processes of 'domestication' of leisure began, clearly due to the improvement of the equipment of cultural home leisure; substantial and organizational backlog of public leisure forms, the inconsistency of club services to the needs of the population; and the growing role of amateur associations outside the club. As a result, public clubs were losing popularity and their attendance was decreasing. At the same time, disorganized amateur activity became widespread, especially in the youth environment. The forms of its manifestation are varied: teenagers and youth companies focusing on 'street' communication, youth parties, and 'underground' rock groups. Informal youth associations were spreading: hippies, punks, rockers, breakers and sports fans. Interest in informal amateur activity grew, clubs for running, dancing, and music arose; amateur activity has often grown into artistic creativity, acquiring the character of a homebased hobby that is realized in family circles and friendly companies.

Many of the tools, forms and methods used in Soviet clubs are still relevant today: theme nights, theatrical holidays, concert programs, club lounges, recreational games, festivals and children's mornings, etc. Instead, such forms of club work as the days of revolutionary and martial traditions were losing their significance; People's Universities; performances of agitation units, agitation theatres, agitation and art associations, agitation and cultural crews; evening rallies, evening rituals; reading aloud; discussion of newspaper publications, reference desk and other activities. Not used in club practice are such forms of visual propaganda as a satirical newspaper, information leaflets 'Lightning' (announcement of an urgent assignment, production victory or award of the collective of a prize or award), 'Glory'

34 Pinalov S. A., Chernyavskiy G. I., Vinogradov A. P. (1983) Istoriya kul'turnoprosvetitel'noy raboty v SSSR [The history of cultural and educational work in the USSR]. Kiev: Vishcha shkola. (in Ukrainian) 
(glorification of worthy imitation), 'Anxiety' (signals about underperformance, backlog, failure to complete tasks); radio newspaper; campaigning corners; message boards; educational booth or poster.

Significant changes in the activities of clubs took place in the mid-1980's they are primarily related to socio-political changes in society. Abandoning such traditional areas of work as science, technology, ideology, party propaganda, clubs focused on leisure activities, focusing on the specific interests of visitors in their free time. In addition to the traditional ones, some clubs have started functioning informal associations: fan clubs, rock clubs, breakdancing and scratchboards, etc. The main functions of the club remained educational, enlightenment, creative, but began to pay more attention to leisure, communication and recreation, which form the basis of social and cultural activities of the clubs.

\section{CONCLUSIONS}

An analysis of the activities of Ukrainian clubs throughout their historical development allows us to reach the following conclusions. The perception of the club as an institute of culture was formed in England. The following types of clubs have been tried in English socio-cultural practice: taverns and coffee houses; clubs of interest (political, professional, literary and musical), clubs designed for multifunctional leisure activities. The main activities of the clubmen in English clubs were communication and leisure, so communication and leisure functions prevailed. The first Ukrainian aristocratic clubs (beginning of the $19^{\text {th }}$ century) had the features of English clubs: the regulated nature of club membership, aristocracy, exclusivity, elitism and the availability of relevant documents governing the club. However, they systematically carried out cultural and educational activities among the population (folk readings, family evenings, theatre performances and concerts). Despite corporate elitism, the main functions of aristocratic Ukrainian clubs were not only communicative and leisure, but also cultural and educational, which gave impetus to the creation in the late 19th and early $20^{\text {th }}$ centuries powerful people's houses, people's theatres, people's universities and 'culturally disadvantaged sections of the population'.

Clubs of the Soviet period, transformed from voluntary associations, promoted the ideas of the Bolshevik authorities. Soviet power used the club's capabilities and its potential; the ability to quickly transform into effective and efficient community education and education centres. Despite the clearly defined ideological framework, the transformation of the Soviet clubs from voluntary associations to public institutions of club type, whose activity is closely aligned with the political interests of the country; that the clubs of the 
Soviet model became a kind of official representatives of local authorities, whose main task was to socialization, Sovietisation and politicization of traditional rural and urban leisure activities, attracting people to officially authorized and recommended by authorities of social and cultural activities, it should be noted that in Soviet times was very positive. In particular, new types of club-type establishments: cultural-educational and propaganda centres, houses of culture, rural buildings, reading-houses, mobile clubs, experimental and experimental clubs; new forms and methods of work: agitation courts, stage performances, agitation campaigns, live Newspapers, 'red' and 'black' boards, 'leaflets-lightning', evenings of labour glory, thematic evenings, amateur performances, radio newspapers; established scientific and methodological and personnel support of club institutions, their cinema and technical equipment, financing and material support and extensive infrastructure of club institutions, which allowed to cover all segments of the population.

Thus, analysing the historical way of formation and development of clubs in Ukraine, it can be noted that their activity has always been determined by the peculiarities of social, political and socio-economic processes.

\section{SUMMARY}

The article analyses the formation and development of clubs, reveals the positive achievements and miscalculations at different stages of historical development. It has been found that the traditional gatherings of young people are 'streets', 'musicians', 'evenings', 'parties' and 'dawns' as prototypes of domestic clubs. The first aristocratic clubs in the territory of Ukraine, according to the English model, appeared in the early of the 19th century and represented the characteristic features of English clubs.

In particular, the regulated nature of club membership, aristocracy, exclusivity, elitism, the availability of appropriate documents governing the club.

In the early of the 20th century, voluntary clubs have been transformed into club-type institutions funded and managed by public authorities.

The article reveals the activity of Soviet clubs, which is closely connected with the political interests of the country, and proves that the clubs of the Soviet model became a kind of official authorities in the field, whose main task was to socialize, Sovietize and politicize traditional rural and urban leisure, to involve officially approved and recommended forms of sociocultural activity by the authorities.

The most widespread forms of club work of all periods of development outlined in the study are identified. 


\section{REFERENCES}

1. Andreeva M. S., Vinogradov A. P., Pinalov S. A., Chernyavskiy G. I. (1970) Istoriya kul'turno-prosvetitel'noy raboty v SSSR. Sovetskiy period (1917-1969) [The history of cultural and educational work in the USSR. Soviet period (1917-1969)]. Khar'kov: KhGIK. (in Ukrainian)

2. Baghmut I. A. (1927) Chervoni kutky na seli (kutkovi khaty chytaljni) [Red corners in the countryside (corner reading rooms)]. Kiev: Derzhavne vydavnyctvo Ukrajiny. (in Ukrainian)

3. Berezin B. I. (1989) Sovetskiy klub : sostoyanie i perspektivy razvitiya [Soviet club: state and development prospects]. Moscow: VIPKRK. (in Russian)

4. Bosyk Z. O. (2010) Vechornyci ta dosvitky [Evenings and sunrises]. Pam'jatka-zapytaljnyk na dopomoghu zbyracham ukrajinsjkoji usnoji narodnopoetychnoji tvorchosti [Questionnaire for help to collectors of Ukrainian oral poetry]. Kiev: NAKKKiM, pp. 46-51.

5. Brokgauz, Efron (1900) Klub [Club]. Entsiklopedicheskiy slovar' [Encyclopedic Dictionary]. Cankt-Peterburg: Izdateli Brokgauz, Efron, pp. 1119.

6. Cherkezov G. (1912) Vneshkol'noe popechenie o detyakh [Extracurricular care for children]. Prakticheskaya shkol'naya entsiklopediya [Practical School Encyclopedia]. - Moscow: Tipografiya T. P. Ryabushinskogo, pp. 709-715.

7. Darvin B. British clubs (British in pictures). - London, 1943. $-48 \mathrm{p}$.

8. Fitzgerald P. The History of Pickwick. - London, 1891. - 375 p.

9. Fostun S. M. (1999) 130-richchja Tovarystva "Prosvita" [Prosvita Society's 130th Anniversary], Vyzvoljnyj shljakh : suspiljno-politychnyj i literaturnyj misjachnyk, vol. 1, pp. 13-24.

10. Ghrycenko O. A. (1998) Klub [Club]. Narysy ukrajinsjkoji populjarnoji kuljtury [Essays on Ukrainian Popular Culture]. Kiev: UCKD, pp. 245-259.

11. Griffiths M.A. Clubs and clubmen. - London, Hutchinson and Co. London, 1907. - 343 p.

12. Gurevich A. Ya. (1972) Kategorii srednevekovoy kul'tury [Categories of medieval culture]. Moscow: Iskusstvo. (in Russian)

13. Klyusko E. M. (1999) Kul'turno-dosugovaya deyatel'nost' naseleniya Rossii (may 1945-1985 gg.) : Teoretiko-metodologicheskiy i istoricheskiy aspekty [Cultural and leisure activities of the population of Russia (May 1945-1985): Theoretical, methodological and historical aspects]. Moscow: MGUKI. (in Russian)

14. Komissarenko S. (1997) Angliya : klubnye traditsii [England: club traditions]. Klub, no. 11, p. 18. 
15. Komissiya narodnykh chteniy v Kieve (1888) Otchet komissii narodnykh chteniy v Kieve za 1882-1887 gg. [Report of the commission of public readings in Kiev for 1882-1887]. Kiev: Tipografiya shtaba Kievskogo voennogo okruga. (in Ukrainian)

16. Petrova I. V. (2005) Osoblyvosti funkcionuvannja sfery dozvillja u radjansjkij Ukrajini (1917-1939) [Features of Functioning of Leisure Sphere in Soviet Ukraine (1917-1939)]. Visnyk KNUKiM, vol. 13, pp. 117-124.

17. Petrova I. V. (2008) Kuljturologhichni chynnyky rozvytku dozvillja v Ukrajini pislja socialistychnoji revoljuciji [Cultural factors of leisure development in Ukraine after the socialist revolution], Visnyk Derzhavnoji akademiji kerivnykh kadriv kuljtury i mystectv, no.4, pp. 21-26.

18. Pinalov S. A., Chernyavskiy G. I., Vinogradov A. P. (1983) Istoriya kul'turno-prosvetitel'noy raboty $\mathrm{v}$ SSSR [The history of cultural and educational work in the USSR ].Kiev: Vishcha shkola. (in Ukrainian)

19. Ponomarjov A. (1996) Tradycijni normy povedinky i dozvillja [Traditional standards of behavior and leisure]. Etnichnistj ta etnichna istorija Ukrajiny [Ethnicity and Ethnic History of Ukraine] (Elektronnyj resurs). Retrieved from: http://libr.org.ua/book/78/ 2397. html (accessed 10.12.10).

20. Sadyrin K. (1912) Narodnye universitety [People's universities]. Prakticheskaya shkol'naya entsiklopediya [Practical School Encyclopedia]. Moscow: Tipografiya T. P. Ryabushinskogo, pp. 597-614.

21. Timbs J. Club life of London during the 17th, 18th and 19 th centuries. In two volumes. London, 1866. V. $1.364 \mathrm{p}$.

22. Tuev V. V. (1997) Istoriya kluba : ot neinstituirovannykh form klubnogo obshcheniya do pervykh organizatsiy klubnogo tipa [Club history: from non-institutional forms of club communication to the first club type organizations]. Kemerovo: KGIIK (in Russian)

23. Tuev V. V. (1998) Fenomen kluba : Istoriko-pedagogicheskiy analiz [Club Phenomenon: Historical and Pedagogical Analysis] (PhD Thesis), Moskva: Moskovskiy gosudarsvennyy universitet kul'tury

24. Ustinova Yu. B. (1988) Chastnye kul'tovye soobshchestva u grekov [Private cult communities of the Greeks]. Byt $\mathrm{i}$ istoriya $\mathrm{v}$ antichnosti [Life and history in antiquity]. Moscow: Nauka, pp. 192-218.

25. Verzhbitskiy K. V. (1999) Traditsionnye formy obshcheniya u rimlyan i oppozitsiya Yuliyam-Klavdiyam [Traditional forms of communication among the Romans and opposition to Julius-Claudius], Vestnik SanktPeterburgskogo universiteta, vol. 2, pp. 104-107.

26. Volodina O. V. (2014) Realizatsiya pedagogicheskogo potentsiala uchrezhdeniya kul'tury klubnogo tipa [Realization of the pedagogical potential of a club-type cultural institution] ( $\mathrm{PhD}$ Thesis), - Stavropol', Severo-kavkazkiy gosudarstvennyy tekhnicheskiy universitet. 
27. Vyguzova E. V. (2005) Elitarnye kluby v kul'turnom prostranstve Rossii kontsa XVIII - nachala XX vv. [Elite clubs in the cultural space of Russia in the late 18th - early 20th centuries] (PhD Thesis), Ekaterinburg: Ural'skiy gosudarstvennyy universitet im. A. M. Gor'kogo

28. Wertheimer J. The Law relating to clubs by M.Turner and A.S. Wilson. London : Swell and Maxvell, 1903. 236 p.

29.Zakovych M. M. (ed.) (2004) Kuljturologhija : ukrajinsjka ta zarubizhna kuljtura [Culturology: Ukrainian and foreign culture]. Kiev: Znannja. (in Ukrainian)

30. Zharkov A. D., Chizhikov V. M. (ed) (1998) Kul'turno-dosugovaya deyatel'nost' [Cultural and leisure activities]. Moscow: MGUK. (in Russian)

Information about the author:

Polishchuk Liudmyla,

Candidate of cultural science, Assistant professor,

Associate Professor of Event Management and Leisure Industry Department Kyiv National University of Culture and Art Kiev, str., Konovalets 36, office 415

ORCID 0000-0002-4572-7647 